\title{
Are IPO underwriters paid for the services they provide?
}

\author{
Michele Meoli $^{a, b}$, Andrea Signori ${ }^{a *}$, Silvio Vismara ${ }^{a, b}$
}

July 9,2012

\begin{abstract}
The level of competition in the industry of IPO underwriting has been under discussion since Chen and Ritter (2000) pointed out an unusual clustering of gross spreads at seven percent, involving almost all moderatesized IPOs in the US. In Europe, underwriting fees are significantly lower and not as clustered. We find that the firms going public in Europe usually pay fees between 3 and 5 percent, but sometimes as low as 1.25\%. Only $12 \%$ of European IPOs pay the median spread of four percent, while $76 \%$ of US IPOs pay the median of seven percent. This variability makes Europe a privileged setting for investigating the determinants of underwriter remuneration.

More reputable underwriters are paid more for taking companies public, because they are expected to provide a better service. However, independently from their reputation, underwriters provide different optional services to the issuer. We question whether the services provided are related to the gross spreads and find that asking underwriters to stabilize the price does increase the spread, whereas liquidity support does not drive the spread. We further investigate whether the underwriters' declarations are actually pursued in the aftermarket, and find that underwriters do act according to the issuers' interests when providing price stabilization, while such an alignment of incentives is not as clear in the provision of liquidity support.
\end{abstract}

Keywords: IPOs, Underwriters, Investment banks, Gross spread, Price stabilization.

JEL Code: G15, G24

a Department of Economics and Technology Management, University of Bergamo, Italy

b CCSE, University of Bergamo, Italy, and University of Augsburg, Germany

\footnotetext{
* We are grateful to Stefano Paleari, Jay Ritter, participants in the 2011 FMA European Conference in Porto (in particular, the discussant Wolfgang Bessler), the 2012 EFMA Annual Meeting in Barcelona (in particular, the discussant Wolfgang Aussenegg), and seminars at the Italian Stock Exchange and at Manchester Business School, for helpful comments. We are thankful to Fabio Braga, Enrico Pellizzoni and Borsa Italiana for providing the data and useful insights.

Contact author: viale Marconi 5, 24044 Dalmine (BG), Italy, andrea.signori@unibg.it.
} 


\section{Introduction}

The level of competition in the industry of IPO underwriting has been under discussion since Chen and Ritter (2000) pointed out an unusual clustering of gross spreads at seven percent, involving almost all moderatesized IPOs in the US. They argue that an implicit form of collusion (strategic pricing) might have been adopted. Eleven years later, Liu and Ritter (2011) address the inconsistency of perfect competitive models and study the US underwriting industry as a series of local oligopolies. The principal sources of market power they identify are quality, which involves the reputation of the underwriters, industry expertise, and the ancillary services provided.

Chen and Ritter (2000) and Liu and Ritter (2011) deal with IPOs in the United States. Europe presents a different story, in that underwriting fees are significantly lower (Ljungqvist et al. 2003). Our own data confirm a gap of three percentage points between the average underwriting fees in the US and Europe. Several reasons have been proposed to justify this difference, such as higher quality of services (Torstila 2003) or stronger litigation exposure (Lowry and Shu 2002). A recent paper by Abrahamson et al. (2011), however, argues that the gap can only barely be justified by the higher marketing costs, legal expenses and litigation exposure of US underwriters combined. A more plausible explanation is the different levels of competition in the two underwriting markets.

Underwriting fees are also not as clustered in Europe as they are in the US (Torstila 2003). We find that the firms going public in Europe usually pay fees between 3 and 5 percent, but sometimes as low as 1.25\% (e.g., the Peacock Group in London in 1999, or Snam Rete Gas in Milan in 2001). Only 12\% of European IPOs pay the median spread of four percent, while $76 \%$ of US IPOs pay the median of seven percent. This variability makes Europe a privileged setting for investigating the determinants of underwriter remuneration.

This paper relates the fees paid to underwriters (gross spreads) to the nature and quality of the services they provide. Some services are granted in every IPO (e.g., due diligence, roadshows, book building, and placement), others are others are optional (e.g., price stabilization and liquidity support). The quality of the 'standard' services required in every IPO are related to several factors, such as the characteristics of the firm going public, the risk of the offering, and the quality and reputation of the underwriter. The provision of ancillary services is instead specific to the offering. Ceteris paribus, investment banks should charge higher fees if they offer ancillary services. Price stabilization and liquidity support are particularly crucial for the success of an IPO (Ellis et al. 2000), We test whether they drive up the underwriting fees.

We model the gross spread as a function of three types of variables: (1) firm-specific, (2) underwriterspecific, and (3) IPO-specific. First, the nature of the company going public is expected to affect the level of fees. For instance, larger firms may be expected to pay less than small firms, as do privatizations and ECOs (Torstila 2001b). In the second category, the reputation or perceived quality of the underwriter is a source of bargaining power that raises fees (Fang 2005). Thus, we control for the ranking and internationality of the underwriter. The third category takes into account the level of services provided in the deal. This last aspect 
represents the main novelty of our paper, in that the model investigates whether a formal commitment of the underwriter to provide ancillary services leads to higher fees.

The official prospectus declarations, though not binding, disclose whether underwriters are 'available' to provide liquidity support and/or stabilize the price in the first month of trading ${ }^{1}$. However, one obstacle with testing is that underwriters do not formally commit to price support, nor do they publicly disclose stabilizing activities. They decide ex post whether, and how much, to stabilize. Perhaps, a legally binding contract could be too costly to define and to enforce (Lewellen 2006). Since trading activity may be profitable for underwriters, they may be motivated to intervene also when not needed. Vice versa, they may be reluctant to stabilize the price of IPOs when it is costly. We therefore investigate whether the availability to provide ancillary services, declared ex ante, allows underwriters to charge higher fees.

The empirical setting of our paper is Italy, where we can access unique data provided by the stock exchange (Borsa Italiana), including detailed information on the fees charged by underwriters as well as on their services. Investigating the Italian underwriting market may be instructive. First, its institutional setting is similar to most continental European countries, but significantly different from the US market (Abrahamson et al. 2011). In the US, IPO allocation policies are discretionary for both retail and institutional investors (Ljungqvist and Wilhelm 2003), while in Europe shares cannot be discretionarily allocated to retail investors (Jenkinson and Jones 2004). Second, in the Italian market we can study the decision to go public outside of the Anglo-Saxon financial system (Pagano et al. 1998). Both the UK and the US have well-developed equity markets, and a related industry of financial intermediation centered on providing equity (La Porta et al. 1997). Our analysis sheds light on financial intermediation of IPOs in a bank-centered system.

Results reveal that firm and offer characteristics do drive underwriting fees, because economies of scale are influential and because reputable banks are able to charge a premium. Underwriters are also paid to stabilize stock prices, and issuers can pay lower fees by accepting the risk of no aftermarket support. Only half of the IPOs that require this service are actually stabilized after going public. These offerings exhibit poor aftermarket performance, therefore underwriters seem to act properly by stabilizing those IPOs that actually need it. The nationality and reputation of the underwriter are also crucial in the stabilization decision: foreign and highly ranked banks act less promptly to support stock prices, probably because they take public only high-quality firms that are less likely to underperform. Conversely, liquidity support is carried out in $90 \%$ of the cases in which the underwriter was asked to provide it, if necessary. However, underwriters support more frequently IPOs taking place during a positive market momentum, raising concerns about the alignment of incentives in the provision of this service.

The remainder of the paper is organized as follows. Section 2 provides a review of the literature on competition in the underwriting industry and gross spread determinants. Section 3 describes the IPO

\footnotetext{
${ }^{1}$ A firm that goes public is required to publish a prospectus. This requirement is based on the governing regulations of the stock exchange where the firm is to be listed. Van der Goot (2003) presents and compares the prospectus liability with particular reference to the role of financial intermediaries in Europe.
} 
underwriting industry in Europe. Section 4 explains the research design and methodologies. Results are summarized in Section 5, and Section 6 concludes the article.

\section{Literature review}

In the US, IPOs widely adopt the 'seven percent solution' regardless of offer size and underwriting costs (Chen and Ritter 2000). Moreover, underwriters who persistently underprice IPOs experience superior market share growth, instead of being penalized for leaving money on the table (Hoberg 2007). This empirical evidence of spread clustering and 'underwriter persistence' is inconsistent with most of the asymmetric, information-based models that attempt to explain IPO equilibrium, such as winner's curse (Rock 1986), signaling (Allen and Faulhaber 1989) and litigation (Beatty 1993). Liu and Ritter (2011) argue that the underwriting market in the US is best represented as a series of local oligopolies, where the quality of ancillary services determines market power and underwriters exercise this power through underpricing rather than by charging higher fees. Hence, in equilibrium, neither underpricing nor spread is competitive.

Chen and Ritter's (2000) original implicit collusion hypothesis is challenged by another line of research. Hansen (2001) claims that seven percent is simply the efficient contract that best suits the IPO market, because its low concentration and weak entry barriers are inconsistent with collusive practices. Torstila (2003) documents that clustering also occurs outside the US, though less pervasively, and need not originate in collusive behavior. Yeoman (2001) emphasizes that spreads are negotiated at the beginning of the IPO process, when the expected outcome is still very uncertain. Thus, issuer and underwriter cannot identify the optimal spread and favor the seven percent solution to drop contracting costs.

However, efficiency-based models are unable to justify the 3\% gap between European and US fees. Abrahamson et al. (2011) find that this difference persists even after subtracting legal costs, which are not included in European spreads. They wonder why, given that the same banks dominate both markets, US issuers are not charged European fees. The most plausible explanation is the higher level of competition in the underwriting market in Europe.

The issuer's and the underwriter's characteristics are widely recognized as crucial elements in determining the level of fees. For instance, fees decrease with offer size due to substantial economies of scale (Ritter 1987). Underwriters receive a lower remuneration also in privatizations (Torstila 2001b), and in venturebacked IPOs (Francis and Hasan 2001). On the underwriter's side, reputation is crucial. Reputable banks charge a premium because they are able to obtain a higher price for the issuer (Chemmanur and Fulghieri 1994) and because they also play a certifying role (Booth and Smith 1986). In particular, US banks operating in European markets are more costly because of their expertise in case the IPO has to be marketed in the US (Torstila 2001b). 
However, despite the growing interest in explaining the underwriters' remuneration, no existing study asks whether ancillary services affect the gross spread. The only study on this question is Torstila (2001a), whose prediction that stabilization costs are anticipated by the level of fees finds no empirical support. Yet the provision of underwriting services can be subject to opportunistic behaviors. For instance, discretionary power in the allocation of shares allows underwriters to give preference to rent-seeking investors in hot IPOs, in exchange for larger-than-normal trading commissions. The excess execution costs are known as soft dollars (Loughran and Ritter 2002). Hot issues may also be allocated to company executives, in order to influence their decisions in hiring underwriters for their own companies' future IPOs and SEOs (Liu and Ritter 2010). The underwriters' conduct after the issue, when price stabilization and liquidity support services are provided, also remains opaque (Aggarwal 2000). Ellis et al. (2000) demonstrate that underwriters take substantial inventory positions when stabilizing stock price, and both stabilization and liquidity provision are intrinsically profitable activities.

\section{IPO underwriting in Europe}

Figure 1 shows the distributions of gross spreads for US IPOs and European IPOs in the period 1999-2008. More than half $(76 \%)$ of US IPOs have fees at exactly seven percent. Among European IPOs, there is a difference of $2 \%$ between the first and third quartiles.

[FIGURE 1]

This paper focuses on the IPO market in Italy, for which we have data on the entire population of IPOs in the period 1999-2008 ${ }^{2}$. The IPO process in Italy is briefly outlined in Table 1. The pre-listing phase includes 'standard' services: the typical marketing, pricing and placement activities mandatory in all IPOs. The underwriter's mandate does not end with the beginning of trading, since it often guarantees the subscription of all or part of the unsold shares, if any. Moreover, the lead underwriter and the specialist are involved in providing two aftermarket services ${ }^{3}$. Price stabilization consists in purchasing shares in the aftermarket in

\footnotetext{
${ }^{2}$ Data on underwriter services in the aftermarket are provided by Borsa Italiana only until 2008. In Italy, Issuers can choose among three public markets managed by Borsa Italiana: the MTA (Mercato Telematico Azionario), which is the main market; the Expandi, dedicated to small companies (the minimum capitalization is one million euros); or the Nuovo Mercato, for young firms in high-tech industries.

${ }^{3}$ In Italian IPOs, the underwriting syndicate is typically composed of three members: the lead underwriter (or 'global coordinator'); the sponsor, who is in charge of complying with disclosure and transparency rules; and the specialist, who provides liquidity in the aftermarket. In about one-third of our sample, the lead underwriter and the specialist are the same bank. We have data on the gross spread paid to the underwriting syndicate, but no information is available about its division among the different members of the syndicate. The gross spread is the commission that comprehends all the services provided by the underwriting syndicate. The roles and services provided by the underwriting syndicate in Italy, as described in this paper, are similar in France and Germany, as reported in Georgen et al. (2009).
} 
order to prevent price drops, and is provided by the underwriter as soon as the stock price goes below a certain threshold (typically, the offer price). Liquidity support is performed by the specialist, that posts bid and ask proposals to avoid excessively wide bid-ask spreads and facilitate trading activity. Although both these services are carried out during the first 30 days by means of aftermarket trading, the main difference is that while stabilization is performed in reaction to price downturns, liquidity support is provided when the bid-ask spread becomes too wide ${ }^{4}$.

Allocation devices such as overallotment, naked short position, and greenshoe option are crucial for both the decision and the extent of price stabilization. The overallotment option is an agreement between the issuer and its underwriter that allows the underwriter to sell additional shares up to a maximum of $15 \%$ of the offered volume., by borrowing additional shares from existing shareholders. Overallotment can be either covered by giving back the corresponding amount of money (greenshoe) or shares (stabilization) to the lenders, or by a combination of the two. The greenshoe option allows underwriters to leave the additional shares on the market and pay them back at the offer price, regardless of current market valuation. Conversely, price stabilization consists in the underwriter repurchasing shares in the aftermarket, and giving them back to the lenders.

Both greenshoe option and price stabilization can be performed till 30 days after the beginning of trading activity. Although they are not mutually exclusive, the key determinant of the choice should be aftermarket stock price: if the IPO is traded above the offer price, buying shares at the current market valuation (i.e. stabilizing) would be more costly than exercising the greenshoe option. Vice versa, if the IPO is traded below the offer price, paying back the shares at the offer price (i.e. exercising the greenshoe) would imply a loss. Hence, stabilization is typically associated with bad performing IPOs. Underwriters may also take an initial short position even in excess of $15 \%$ of the offering, known as 'naked short' position. In this case, the underwriter knows ex ante that it will have to engage in price stabilization.

\section{[TABLE 1]}

\section{Research design}

\subsection{Data and methodology}

We collect information on the characteristics of firms, offers, and underwriting syndicates directly from IPO prospectuses. Information regarding price stabilization and liquidity support is provided by Borsa Italiana through the MarketConnect database. In particular, we access the amounts of shares bought and sold by

\footnotetext{
${ }^{4}$ There is no threshold set by regulatory authorities that triggers liquidity support. The specialist and the issuer arrange the terms of this service discretionarily.
} 
underwriters both for stabilization and liquidity support purposes, throughout the first month of trading. This information allows us to identify which IPOs are price-stabilized and/or liquidity-supported by underwriters, and to what extent ${ }^{5}$.

We run three types of regressions. First, we use a cross-sectional OLS model to investigate the influence of ancillary services on the gross spread. Second, we study the ancillary service of price stabilization. Since the intensity of this activity is observable only when the underwriter decides to intervene, we correct for selection bias by employing a two-step Heckman procedure. In the first step, the dependent variable is a dummy related to the underwriter's decision. The critical determinant is aftermarket performance, which is endogenous because it is in turn influenced by the underwriter's intervention. Thus, we adopt an instrumental variable approach by employing a set of instruments aimed at identifying bad performing IPOs. In the second step, we study the determinants of the intensity of price stabilization, with the dependent variable measuring the quantity of shares purchased by the underwriter during the provision of this service, scaled by the first month turnover. An analogous selection issue arises for liquidity support. However, since declaration is not substantiated in only 6 cases, the estimation of Heckman's first step would become ineffective. Thus, we employ a Tobit model treating the dependent variable as censored at zero in absence of this service.

\subsection{Variables}

Table 2 summarizes the definitions and theoretical justifications of the variables included in the gross spread regression. We consider variables in three categories: (1) firm and offer characteristics; (2) underwriter characteristics; (3) and their actual provision of ancillary services.

In the first group, we employ firm age at the IPO as a proxy for maturity, while size controls for economies of scale. We also include relative issue size, dilution ratio, and institutional allocation. Since underwriting IPOs in a very hot period may require lower effort by investment banks, with potential reductions in fees, we add the return of the FTSE Italia MIB index 100 days before the listing date (pre-IPO market return), and the number of IPOs in the previous twelve months (market momentum). Finally, we include price revision, the greenshoe option, claw-back clauses ${ }^{6}$, and underpricing to see whether the gross spread has any predictive power regarding their use.

The second set of determinants is related to the underwriter. First, we include a dummy to indicate when non-Italian banks are involved in the process. The underwriter's reputation is proxied by its market share

\footnotetext{
${ }^{5}$ Stabilization data are disclosed in a report transmitted to Borsa Italiana by the underwriter at the end of the first trading month, and is available for all IPOs. Liquidity support is identified by a flag on trades accomplished to this purpose, although we have no information for 40 of the 87 offerings in which a specialist (liquidity provider) was designated.

${ }^{6}$ Claw-back clauses are provisions allowing the underwriter to shift shares from one investor category to another, in order to manage different levels of oversubscription. Bertoni et al. (2008) find that underwriters in Italy increase the fraction of the shares allotted to the public when the first day return is negative.
} 
(proceeds) in the Italian market ${ }^{7}$. The size of the underwriting syndicate is also included, because large syndicates allow to share the IPO risk (Torstila 2001b).

Finally, the third group contains explanatory variables. Two dummies identify IPOs that did not require price stabilization and liquidity support ex ante. The aim is to test whether issuers have the possibility to pay lower fees by renouncing the underwriter's formal commitment to provide these services.

[TABLE 2]

\subsection{Sample}

The sample consists of 171 IPOs taking place in Italy in the period 1999-2008. The median gross spread in Italy is $4 \%$, as reported in Table 3. Two important factors affect the gross spread. The first is economies of scale. Within the Blue Chip segment, where the average size of IPOs is 1.5 billion euros, the median spread is only $2.7 \%$. The second factor is uncertainty. The highest fees are charged in the Nuovo Mercato, where young (the median age is 8 years at the IPO) and riskier firms typically go public. Higher exchange listing standards are indeed proven to screen out companies that are less prepared to go public (Johan 2010), that in turn may opt for second-tier, less regulated markets (Vismara et al. 2012). Here the median spread for underwriters is $4.70 \%$. There are other peculiarities of the Nuovo Mercato. First, IPOs in this market benefit from a favorable market momentum, with an average of 32 offerings in the prior year, since most of these IPOs took place during the tech bubble period (1999-2000). They also show the highest dilution ratio (32.2\% on average) and the deepest underpricing ( $21.7 \%$ on average ${ }^{8}$. The Blue Chip segment is characterized by the highest level of underwriter reputation (39.8\% on average) and the strongest presence of foreign banks (38.9\%). They underwrite the $23 \%$ of the sample, and are totally absent from the Expandi market. The overallotment and the exercise of the greenshoe option are quite common practices, occurring in approximately $60 \%$ of the IPOs. Conversely, underwriters assume a naked short position only in $4.7 \%$ of the cases. Approximately half of the IPOs are actually stabilized.

\section{[TABLE 3]}

\footnotetext{
${ }^{7} \mathrm{We}$ also defined underwriter reputation with reference to the number of IPOs managed instead of capital raised, finding similar results. These models are not reported in this paper.

${ }^{8}$ The average value of the Standard segment is inflated by the $532.6 \%$ underpricing of Finmatica, gone public on the main market in November 24, 1999, and then transferred to the newly launched Nuovo Mercato in October 16, 2000.
} 
The 171 IPOs of the sample are underwritten by 31 different investment banks, as reported in Table 4. Italian banks underwrite approximately three-quarters of the IPOs (Panel A of Table 4). Mediobanca is the "national champion', with the largest amount of capital ( $24 \mathrm{€m}$, almost half of the total), while Intesa Sanpaolo underwrites the largest number of deals (48 IPOs, $28 \%$ of the total). Among foreign banks, five of the top six underwriters are based in the US. Foreign banks tend to be involved in larger syndicates, with an average membership of 2.6, while Italian banks are more willing to operate in small groups or even alone. Contrary to their domestic behavior and the results documented by Torstila (2001b), US banks are among the cheapest underwriters when operating in Italy. Their average fees range from $2.05 \%$ (Goldman) to $4.11 \%$ (Citigroup). However, in Italy US banks underwrite only the largest offers.

[TABLE 4]

\section{Results}

\subsection{Gross spread determinants}

Table 5 reports the regression results ${ }^{9}$. Underwriters that took companies public during the tech bubble (1999-2000) charge a fee premium due to the higher risk associated with offerings mainly conducted by small firms with no established track records and uncertain growth prospects. Predictably, firm and offer characteristics affect the level of underwriters' remuneration. According to Torstila (2001b), there are at least three explanations for the negative impact of size. First, IPOs have fixed costs, such as prospectus preparation, marketing and consulting, which become less significant as offerings grow larger. Second, the size of the IPO is inversely related to risk, in that smaller companies are typically subject to higher uncertainty. Third, large IPOs are more sought after by investment banks, so competition may result in lower fees. In less diluted offerings, suggesting an exit rather than a growth strategy of the firm going public, and in presence of lower institutional participation, signaling weak interest by well-informed investors, underwriters charge higher fees.

Prestigious banks benefit from a significantly positive fee premium. Increased bargaining power and the issuers' perception that these banks are able to provide higher quality services are both plausible explanations. We also find that issuers that do not require ex ante the stabilization service pay lower fees. If a firm going public is willing to bear the risk of no aftermarket support, it can save on the remuneration of its investment bank. Finally, the level of fees does not anticipate whether prospectus declarations will be pursued or not, for both the two ancillary services.

\footnotetext{
${ }^{9}$ As the Breusch-Pagan test detects the presence of heteroskedasticity, we use White's heteroskedasticity-consistent standard errors. Variance inflation factors for the independent variables are reported in Appendix 1.
} 


\section{[TABLE 5]}

\subsection{Underwriter's behavior in the aftermarket}

We now examine the underwriters' conduct in providing price stabilization and liquidity support. Figure 2 offers a clear picture of how underwriters cover the initial short position, undertaken in $62.6 \%$ of the IPOs. The graph refers to the end of the first month of trading, and shows the average fraction covered by exercising the greenshoe option, and the average fraction covered by stabilizing the IPO, both expressed in percentage of the initial short position (i.e., 100\% corresponds to the sum of overallotment and naked short, if any). IPOs are categorized in four groups, according to the number of days within the first month in which the IPO is traded below the offer price.

[FIGURE 2]

The largest fraction of short position is covered using the greenshoe option, which is exercised at a nearly constant rate, regardless of price trends. This is not particularly surprising, as underwriters have the incentive to exercise the greenshoe even for offerings that trade below the offer price, because they earn fees in percentage of all the shares issued. Price stabilization is more intense in bad performing offerings, confirming that aftermarket performance drives its provision. However, some stabilization activity occurs even when the stock price keeps persistently higher than the offer price. Stabilizing well performing offerings is costly for underwriters, and raises some questions about their behavior in the provision of aftermarket services.

Therefore, we try to unveil the determinants of the stabilization decision using a Heckman selection model. We include overallotment, naked short, and greenshoe dummies to control for short covering (i.e., 'non discretional' stabilization). Price performance during the first month is the driver for the provision of this service, but it is in turn influenced by stabilization activity, hence endogenous. Therefore, we adopt an instrumental variable approach by employing the following instruments for the 1-month buy-and-hold abnormal return: pre-IPO market return, market momentum, underpricing and claw back clauses to retail investors ${ }^{10}$. The results of this model are shown in Table 6 .

\footnotetext{
${ }^{10}$ Endogeneity is verified through Hausman (1978) test. Valid instruments must both explain stock performance and be uncorrelated with the second stage regression residuals. Once tested their validity, we checked exogeneity with respect to the dependent variable in the main equation and excludability from the regression through Hansens's J test.
} 
Underwriters do seem to support bad performing IPOs. The coefficient of the instrumented variable for the first month buy-and-hold abnormal return is significantly negative, documenting that a poor aftermarket performance triggers the provision of this service. Additionally, IPOs that experience a downward price revision are more likely to be stabilized. Curiously, foreign and more reputable underwriters are less prone to provide this service. This may be explained by the endogeneity of matching between issuer and underwriter (Fang 2005): prestigious banks have stricter standards, so they take public only high-quality firms which are less likely to underperform, and therefore less likely to need price support.

Conversely, gross spread seems to be an ineffective incentive for the undewriter's decision. Surprisingly, the overallotment, greenshoe option, and naked short dummies are not significant, suggesting that underwriters still act with a certain degree of discretion. The second column documents that neither offer size nor the extent of the short position are influential on the intensity of stabilization, measured as the volume of shares purchased to stabilize, scaled by the first month turnover. Instead, the negative coefficient of the fraction of exercised greenshoe confirms its substitutability for price stabilization.

Table 7 reports the results of the Tobit regression models on the provision of liquidity support in the aftermarket. Surprisingly, we find that a positive market momentum is associated with a higher probability and greater intensity of liquidity support. This may raise an issue of misalignment of incentives between the issuer and the underwriter, since IPOs taking place in favorable market conditions should be less exposed to liquidity problems. Performance-related indicators such as price revision and underpricing do not significantly impact the provision of this service, nor do the underwriter's characteristics. Finally, the significance of the stabilization dummy signals a synergy between the two ancillary services: when underwriters engage in price stabilization, they also tend to support liquidity.

\section{[TABLE 7]}

\section{Conclusions}

This paper investigates the relationship between the gross spread paid to IPO underwriters and the level of service they provide, in a sample of 171 Italian IPOs that took place between 1999 and 2008. Specifically, we consider the levels of price stabilization and liquidity support as concretely exercised (aftermarket intervention). We observe that underwriters adopt different behaviors in the actual provision of the two services. While only half of the IPOs with stabilization are then actually supported, almost all liquidity 
declarations are fulfilled in the aftermarket. We thus investigate what are the determinants of the underwriters' decision. In general, they do seem to stabilize IPOs that actually need it, since bad performing offerings experiencing downward price revisions are more likely to be price-supported. Hence, underwriters act according to the issuer's interest. On the other hand, such an alignment of incentives is not as clear in the provision of liquidity support. We also test whether the level of fees anticipates the actual provision of these ancillary services, but the results do not show any predictive power.

This study provides a valuable contribution to the literature on the remuneration of IPO underwriters. While extensive research in the last decade has highlighted the clustering of gross spreads in the US, less effort has been spent investigating the variability of European fees. In particular, the relevance of ancillary services is still unexplored. Our analysis sheds new light on their role in determining fees by documenting a significant impact of the underwriters' stated commitments. The results have direct implications for financial intermediaries, and open a new perspective on sources of market power and differentiation in the underwriting industry. This study also ascertains the behavioral patterns followed by underwriters in the actual provision of services, opening up new directions for future research. For instance, companies going public may design contracting schemes that more effectively align the underwriter's interest with their own. 


\section{References}

Abrahamson M, Jenkinson T, Jones H (2011) Why Don't U.S. Issuers Demand European Fees for IPOs? Journal of Finance 66:2055-2082

Aggarwal R (2000) Stabilization Activities by Underwriters after Initial Public Offerings. Journal of Finance 55:10751103

Allen F, Faulhaber GR (1989) Signalling by underpricing in the IPO market. Journal of Financial Economics 23:303323

Beatty RP (1993) The Economic Determinants of Auditor Compensation in the Initial Public Offerings Market. Journal of Accounting Research 31:294-302

Beatty RP, Ritter JR (1986) Investment banking, reputation, and the underpricing of initial public offerings. Journal of Financial Economics 15:213-232

Benveniste LM, Spindt PA (1989) How Investment Bankers Determine the Offer Price and Allocation of New Issues. Journal of Financial Economics 24:343-361

Booth JR, Smith RL (1986) Capital Raising, Underwriting and the Certification Hypothesis. Journal of Financial Economics 15:261-281

Chemmanur TJ, Fulghieri P (1994) Investment Bank Reputation, Information Production, and Financial Intermediation. Journal of Finance 49:57-79

Chen HC, Ritter JR (2000) The seven percent solution. Journal of Finance 55:1105-1131

Ellis K, Michaely R, O'Hara M (2000) When the Underwriter Is the Market Maker: An Examination of Trading in the IPO Aftermarket. Journal of Finance 55:1039-1074

Fang LH (2005) Investment bank reputation and the price and quality of underwriting services. Journal of Finance 60:2729-2761

Francis BB, Hasan I (2001) The Underpricing of Venture and Nonventure Capital IPOs: An Empirical Investigation. Journal of Financial Services Research 19:99-113

Hansen RS (2001) Do investment banks compete in IPOs?: the advent of the "7\% plus contract". Journal of Financial Economics 59:313-346

Hausman JA (1978) Specification Tests in Econometrics. Econometrica 46:1251-1271

Hoberg G (2007) The underwriter persistence phenomenon. Journal of Finance 62:1169-1206

Jenkinson T, Jones H (2004) Bids and Allocations in European IPO Bookbuilding. Journal of Finance 59:2309-2338 
Johan SA (2010) Listing standards as a signal of IPO preparedness and quality. International Review of Law and Economics 30:128-144

Goergen M, Khurshed A, Renneboog L (2009) Why are the French so different from the Germans? Underpricing of IPOs on the Euro New Markets. International Review of Law and Economics 29:260-271

Kim D, Palia D, Saunders A (2010) Are Initial Returns and Underwriting Spreads in Equity Issues Complements or Substitutes? Financial Management 39:1403-1423

La Porta R, Lopez-De-Silanes F, Shleifer A, Vishny RW (1997) Legal Determinants of External Finance. Journal of Finance 52:1131-1150

Lewellen, K (2006) Risk, Reputation, and IPO Price Support. Journal of Finance 61: 613-653

Liu X, Ritter JR (2010) The economic consequences of IPO spinning. Review of Financial Studies 23:2024-2059

Liu X, Ritter JR (2011) Local underwriter oligopolies and IPO underpricing. Journal of Financial Economics 102:579601

Ljungqvist A, Wilhelm WJ (2003) IPO Pricing in the Dot-com Bubble. Journal of Finance 58:723-752

Ljungqvist AP, Jenkinson T, Wilhelm J, William J. (2003) Global Integration in Primary Equity Markets: The Role of U.S. Banks and U.S. Investors. Review of Financial Studies 16:63-99

Loughran T, Ritter JR (2002) Why don't issuers get upset about leaving money on the table in IPOs? Review of Financial Studies 15:413-444

Lowry M (2003) Why does IPO volume fluctuate so much? Journal of Financial Economics 67:3-40

Lowry M, Shu S (2002) Litigation risk and IPO underpricing. Journal of Financial Economics 65:309-335

Megginson WL, Weiss KA (1991) Venture capitalist certification in initial public offerings. Journal of Finance 46:879903

Pagano M, Panetta F, Zingales L (1998) Why Do Companies Go Public? An Empirical Analysis. Journal of Finance $53: 27-64$

Ritter JR (1987) The costs of going public. Journal of Financial Economics 19:269-281

Rock K (1986) Why new issues are underpriced. Journal of Financial Economics 15:187-212

Torstila S (2001a) The distribution of fees within the IPO syndicate. Financial Management 30:25-43

Torstila S (2001b) What determines IPO gross spreads in Europe? European Financial Management 7:523-541

Torstila S (2003) The Clustering of IPO Gross Spreads: International Evidence. Journal of Financial and Quantitative Analysis 38:673-694 
Van der Goot, T (2003) Risk, the quality of intermediaries and legal liability in the Netherlands IPO market. International Review of Law and Economics 23:121-140.

Vismara S, Ritter JR, Paleari S (2012) Europe's Second Markets for Small Companies. European Financial Management, forthcoming

Yeoman JC (2001) The optimal spread and offering price for underwritten securities. Journal of Financial Economics 62:169-198 
Table 1. The roles of the underwriting syndicate in Italy

List of activities provided by an underwriting syndicate through the IPO process. The 'in charge to' column defines whom, among the syndicate members, is in charge of providing the service.
Service
Description
In charge to

Panel A: pre-listing activities

\begin{tabular}{llc}
\hline $\begin{array}{l}\text { Syndicate coordination } \\
\text { Due diligence }\end{array}$ & Coordination of the underwriting syndicate activities & Lead Underwriter \\
Pre-IPO marketing & Valuation of going public company as potential investment & Lead Underwriter, Sponsor \\
Book building & Roadshow, meetings between top management team and institutional investors & Lead Underwriter \\
Pricing & Gathering information on institutional demand & Lead Underwriter, Specialist \\
Placement & Definition of the offer price & Lead Underwriter \\
Panel B: post-listing activities & Lead Underwriter, Sponsor \\
\hline Underwriting & Subscription of unsold shares, if any & Lead Underwriter \\
Price stabilization & Purchase of shares in the aftermarket & Lead Underwriter \\
Liquidity support & Posting of bid and ask proposals in the aftermarket & Specialist \\
Reporting & Publication of reports and disclosure of price sensitive information & Sponsor, Specialist
\end{tabular}




\section{Table 2. Variable definitions}

\section{FIRM AND OFFER}

Firm age

Size

Relative issue size

Dilution ratio

Institutional allocation

Pre-IPO market return

Market momentum

Price revision

Claw back to retail

\section{Underpricing}

Greenshoe exercised

UNDERWRITER

Foreign underwriter

Underwriter reputation

Syndicate size

ANCILLARY SERVICES (explanatory)

Stabilization not required

Log of 1 plus firm age (in years) at the IPO

Log of IPO proceeds adjusted for inflation, expressed in 2008 Euros

Number of shares offered over pre-IPO outstanding shares

Number of newly issued shares over pre-IPO outstanding shares

Fraction of shares reserved to institutional investors by prospectus

FTSE Italia MIB index return over 100 days prior the IPO

Number of IPOs in the Italian market during the 12 months before listing

Percentage difference between the offer price and the midpoint of the preliminary price range

Fraction of shares shifted from institutional to retail investors after the initial allocation, as percentage of total number of offered shares

Percentage difference between first day official price and offer price

Dummy equal to 1 in case the greenshoe option was exercised

Dummy for non-Italian lead underwriters

Amount of capital raised by the underwriter over the total capital raised in the sample (scaled to $1=$ 'national champion' Mediobanca)

Number of members of the underwriting syndicate

Dummy equal to 1 in case the issuer does not require ex-ante the price stabilization service

Liquidity support not required Dummy equal to 1 in case the issuer does not require ex-ante the liquidity support service

Stabilization performed

Dummy equal to 1 in case the underwriter stabilizes aftermarket stock price

Liquidity support performed

Dummy equal to 1 in case the specialist supports aftermarket liquidity
Higher uncertainty in younger companies

Economies of scale on gross spread

Newly issued shares increase underwriter's valuation uncertainty (Yeoman 2001)

Institutional participation is necessary for an IPO to be successful (Aggarwal 2000)

Market returns capture investment opportunities, investor sentiment and other unknown dynamics (Lowry 2003)

Favorable market sentiment makes trading activity more profitable for underwriters (Ellis et al. 2000)

Price revision should impound public and private information on investor demand gathered in the bookbuilding process (Benveniste and Spindt 1989)

Balance of cold demand of informed institutional investors with hot demand of non-informed retail investors

Spread and underpricing can be correlated (Kim et al. 2010)

Exercising the greenshoe option is a substitute for price stabilization

US banks underwriting European IPOs are more costly (Torstila 2001b)

Reputable banks charge higher fees and provide higher quality services (Fang 2005)

Syndicate size is important for the IPO risk sharing (Torstila 2001b) 
Liquidity support missing

Overallotment

Naked short

Overallotment volume

Greenshoe volume

Naked short volume CONTROL DUMMIES
Dummy equal to 1 in case liquidity support was declared in prospectus but not performed in the aftermarket

Dummy equal to 1 in case the underwriter allocates more shares than made available by the issuer

Dummy equal to 1 in case the underwriter overallocates more than $15 \%$ of the offer volume

Amount of shares over-allocated, as percentage of offer volume

Fraction of greenshoe actually exercised (0-15\% of offer volume)

Fraction of over-allocated shares exceeding the $15 \%$ threshold
Control for short covering in the decision to provide aftermarket support

Control for short covering in the decision to provide aftermarket support

Control for short covering in the intensity of aftermarket support

Control for short covering in the intensity of aftermarket support

Control for short covering in the intensity of aftermarket support

Industries according to the first digit of ICB classification codes; IPO years; privatizations/ECOs (higher bargaining power when negotiating gross spread (Torstila 2001b)); markets and segments (Star, Expandi, Nuovo Mercato); private placings (Beatty and Ritter 1986); VC-backing (Megginson and Weiss 1991). 


\section{Table 3. Descriptive statistics of the sample}

Average and median values (in brackets) of the sample of 171 Italian IPOs from 1999 to 2008. Gross spread is the underwriter's remuneration, in percentage of IPO proceeds. Firm age is the age in years of the company at the IPO; issue size is the amount of proceeds in 2008 Euros; relative issue size is the fraction of offered shares as percentage of pre-IPO outstanding shares; dilution ratio is the percentage of newly issued shares as percentage of pre-IPO outstanding shares; institutional allocation is the fraction of shares reserved to institutional investors by prospectus; pre-IPO market return is the FTSE Italia MIB index return over 100 days prior the IPO; market momentum is the number of IPOs in Italy in the 12 months before the listing; price revision is the percentage difference between offer price and midpoint of the preliminary price range; claw-back to retail is the number of shares shifted from institutional to retail investors, as percentage of the offer volume; underpricing is the percentage difference between offer price and first day official price; underwriter reputation is the fraction of capital raised in the sample, scaled at 1 for the 'national champion' Mediobanca; syndicate size is the number of members of the underwriting syndicate; foreign underwriter is the percentage of IPOs underwritten by a non-Italian bank; overallotment is the percentage of IPOs in which the underwriter sells shares in excess of the offered volume; greenshoe exercised is the percentage of IPOs in which the greenshoe option is exercised; naked short position is the percentage of IPOs in which the underwriter overallocates more than 15\% of the offering; stabilization performed are the IPOs stabilized in the aftermarket; liquidity performed are the IPOs that are actually liquidity-supported. Data on actual liquidity support are available for 46 of 87 IPOs for which a specialist was designated (29 of 32 IPOs in the Star segment).

${ }^{a}$ percentage of firms

\begin{tabular}{|c|c|c|c|c|c|c|c|c|c|c|c|c|}
\hline \multirow{3}{*}{ Gross spread (\%) } & \multirow{2}{*}{\multicolumn{2}{|c|}{$\begin{array}{l}\text { ALL SAMPLE } \\
\text { (171 IPOs) }\end{array}$}} & \multicolumn{6}{|c|}{ MTA (101 IPOs) } & \multirow{2}{*}{\multicolumn{2}{|c|}{$\begin{array}{l}\text { EXPANDI } \\
(29 \text { IPOs })\end{array}$}} & \multirow{2}{*}{\multicolumn{2}{|c|}{$\begin{array}{c}\text { N.MERCATO } \\
\text { (41 IPOs) }\end{array}$}} \\
\hline & & & \multicolumn{2}{|c|}{ BLUE CHIP(18) } & \multicolumn{2}{|c|}{ STANDARD(46) } & \multicolumn{2}{|c|}{ STAR(37) } & & & & \\
\hline & 3.92 & $(4.00)$ & 2.82 & $(2.70)$ & 3.69 & $(3.70)$ & 3.52 & $(3.50)$ & 3.96 & $(3.90)$ & 4.75 & $(4.70)$ \\
\hline Firm age (years) & 32.1 & $(19.0)$ & 41.1 & $(32.0)$ & 49.9 & $(26.0)$ & 35.8 & $(32.0)$ & 27.3 & $(20.0)$ & 9.8 & $(8.0)$ \\
\hline Issue size $(€ \mathrm{~m})$ & 303.0 & $(95.2)$ & $1,704.2$ & $(443.0)$ & 220.0 & (98.5) & 127.0 & $(117.0)$ & 33.6 & (22.6) & 131.3 & $(53.5)$ \\
\hline Relative issue size (\%) & 101.7 & $(38.8)$ & 37.6 & $(38.7)$ & 265.2 & $(38.3)$ & 49.3 & $(45.2)$ & 41.3 & $(37.8)$ & 37.7 & $(31.0)$ \\
\hline Dilution ratio (\%) & 26.5 & $(25.5)$ & 12.3 & (7.1) & 24.9 & (25.0) & 25.5 & $(25.7)$ & 30.8 & $(30.0)$ & 32.2 & $(28.3)$ \\
\hline Institutional allocation (\%) & 74.9 & $(75.0)$ & 70.5 & $(74.5)$ & 70.9 & (75.0) & 77.9 & $(75.0)$ & 86.4 & (86.4) & 70.5 & $(70.0)$ \\
\hline Pre-IPO market return (\%) & 0.9 & $(1.6)$ & 0.7 & (2.9) & -0.3 & $(-0.6)$ & 3.0 & (3.4) & 0.6 & $(3.3)$ & 0.7 & $(-2.0)$ \\
\hline Market momentum (no. IPOs) & 23.7 & $(23.0)$ & 20.5 & $(18.0)$ & 23.5 & (22.0) & 19.8 & $(20.0)$ & 19.1 & (21.0) & 32.1 & $(33.0)$ \\
\hline Price revision (\%) & 28.8 & $(35.1)$ & 33.2 & $(34.1)$ & 38.9 & $(50.0)$ & 22.4 & $(26.8)$ & 33.7 & $(31.7)$ & 18.4 & $(46.9)$ \\
\hline Claw-back to retail (\%) & 5.5 & (1.0) & 9.0 & (4.3) & 6.4 & (3.2) & 4.3 & $(0.9)$ & 4.2 & $(0.0)$ & 4.8 & $(0.9)$ \\
\hline Underpricing (\%) & 12.4 & $(3.5)$ & 3.2 & $(2.1)$ & 17.0 & $(2.5)$ & 3.2 & (1.0) & 9.4 & $(5.8)$ & 21.7 & $(4.2)$ \\
\hline Underwriter reputation (\%) & 22.3 & (6.0) & 39.8 & $(11.5)$ & 21.2 & $(8.0)$ & 29.8 & $(12.0)$ & 14.7 & $(2.0)$ & 14.3 & (3.0) \\
\hline Syndicate size (no.) & 2.1 & (2.0) & 2.3 & $(2.0)$ & 2 & $(2.0)$ & 2.1 & (2.0) & 1.7 & $(2.0)$ & 2.3 & $(2.0)$ \\
\hline Foreign underwriter ${ }^{a}$ & \multicolumn{2}{|c|}{23.0} & \multicolumn{2}{|c|}{38.9} & \multicolumn{2}{|c|}{23.9} & \multicolumn{2}{|c|}{29.7} & \multicolumn{2}{|c|}{0.0} & \multicolumn{2}{|c|}{24.4} \\
\hline Overallotment $^{\text {a }}$ & \multicolumn{2}{|c|}{62.6} & \multicolumn{2}{|c|}{88.9} & \multicolumn{2}{|c|}{58.7} & \multicolumn{2}{|c|}{67.6} & \multicolumn{2}{|c|}{72.4} & \multicolumn{2}{|c|}{43.9} \\
\hline Greenshoe exercised $^{\mathrm{a}}$ & \multicolumn{2}{|c|}{61.4} & \multicolumn{2}{|c|}{88.9} & \multicolumn{2}{|c|}{50} & \multicolumn{2}{|c|}{72.9} & \multicolumn{2}{|c|}{79.3} & \multicolumn{2}{|c|}{39.0} \\
\hline Naked short position ${ }^{\text {a }}$ & \multicolumn{2}{|c|}{4.7} & \multicolumn{2}{|c|}{0.0} & \multicolumn{2}{|c|}{2.2} & \multicolumn{2}{|c|}{0.0} & \multicolumn{2}{|c|}{10.3} & \multicolumn{2}{|c|}{9.8} \\
\hline Stabilization performed ${ }^{a}$ & & & & & & & & .4 & & & & \\
\hline Liquidity support performed ${ }^{a}$ & & & & 0 & & & & .1 & & & & \\
\hline
\end{tabular}


Table 4. Descriptive statistics of IPO underwriters

The sample of 171 IPOs is underwritten by 33 different lead underwriters. The table reports for each of them the number of IPOs underwritten and the capital raised adjusted for inflation (expressed in 2008 Euros). Reputation is measured by a ranking, calculated as the fraction of capital raised in the sample, scaled at 1 for the 'national champion' Mediobanca. Bank names may be different from what reported in prospectus due to M\&As. Banca Commerciale Italiana merged with Banca Intesa in 2001 to form IntesaBci, which in turn merged with Banca Imi in 2006 becoming Intesa Sanpaolo. Capitalia merged with Unicredito Italiano in 2007 to form Unicredit.

\begin{tabular}{|c|c|c|c|c|c|c|c|c|c|}
\hline \multirow[b]{2}{*}{ Lead underwriter } & \multirow{2}{*}{$\begin{array}{c}\text { Capital } \\
\text { raised } \\
(€ \mathrm{~m})\end{array}$} & \multirow{2}{*}{$\begin{array}{l}\text { No. } \\
\text { IPOs }\end{array}$} & \multirow{2}{*}{$\begin{array}{c}\% \\
\text { IPOs }\end{array}$} & \multicolumn{3}{|c|}{ No.IPOs by market } & \multirow{2}{*}{$\begin{array}{l}\text { Average } \\
\text { syndicate } \\
\text { size (no.) }\end{array}$} & \multirow{2}{*}{$\begin{array}{c}\text { Reputation } \\
\text { (ranking) }\end{array}$} & \multirow{2}{*}{$\begin{array}{l}\text { Average } \\
\text { gross } \\
\text { spread }(\%)\end{array}$} \\
\hline & & & & MTA & Expandi & NM & & & \\
\hline \multicolumn{10}{|l|}{ Panel A. Italian banks } \\
\hline Mediobanca & 24,434 & 26 & 15.2 & 20 & 3 & 3 & 2.1 & 1.000 & 3.85 \\
\hline Intesa Sanpaolo & 7,140 & 48 & 28.1 & 27 & 4 & 17 & 1.8 & 0.292 & 4.11 \\
\hline Banca Monte Dei Paschi Di Siena & 2,460 & 1 & 0.6 & 1 & 0 & 0 & 2.0 & 0.101 & 1.95 \\
\hline Intermonte Securities Sim & 2,247 & 5 & 2.9 & 1 & 2 & 2 & 2.6 & 0.092 & 4.05 \\
\hline Unicredit & 1,735 & 9 & 5.3 & 7 & 1 & 1 & 2.0 & 0.071 & 3.58 \\
\hline Banca Leonardo & 825 & 4 & 2.3 & 1 & 0 & 3 & 3.0 & 0.034 & 4.13 \\
\hline Abaxbank & 446 & 10 & 5.8 & 4 & 6 & 0 & 1.5 & 0.018 & 3.73 \\
\hline Bnl & 265 & 2 & 1.2 & 1 & 0 & 1 & 2.5 & 0.011 & 4.73 \\
\hline Euromobiliare Sim & 179 & 3 & 1.8 & 0 & 2 & 1 & 1.0 & 0.007 & 4.17 \\
\hline Banca Akros & 182 & 3 & 1.8 & 0 & 2 & 1 & 2.0 & 0.007 & 4.42 \\
\hline Centrobanca & 126 & 4 & 2.3 & 3 & 1 & 0 & 3.0 & 0.005 & 3.60 \\
\hline Unipol Merchant & 96 & 3 & 1.8 & 0 & 3 & 0 & 1.0 & 0.004 & 4.42 \\
\hline Interbanca & 70 & 3 & 1.8 & 1 & 1 & 1 & 2.3 & 0.003 & 4.40 \\
\hline Banca Finnat & 54 & 2 & 1.2 & 0 & 1 & 1 & 3.0 & 0.002 & 4.00 \\
\hline Banca Nazionale dell'Agricoltura & 46 & 1 & 0.6 & 1 & 0 & 0 & 3.0 & 0.002 & 5.50 \\
\hline Rasfin Sim & 37 & 3 & 1.8 & 0 & 3 & 0 & 2.3 & 0.002 & 4.05 \\
\hline Meliorbanca & 42 & 1 & 0.6 & 0 & 0 & 1 & 2.0 & 0.002 & 4.40 \\
\hline Banca Aletti & 34 & 2 & 1.2 & 1 & 0 & 1 & 1.0 & 0.001 & 3.90 \\
\hline Banca Intermobiliare di Investimenti e Gest. & 28 & 1 & 0.6 & 1 & 0 & 0 & 1.0 & 0.001 & 4.50 \\
\hline Total/average Italian banks & 40,446 & 131 & 77 & 69 & 29 & 33 & 2.1 & 0.087 & 4.08 \\
\hline \multicolumn{10}{|l|}{ Panel B. Foreign banks } \\
\hline JPMorgan Chase (US) & 2,970 & 8 & 4.7 & 5 & 0 & 3 & 2.4 & 0.122 & 3.27 \\
\hline Goldman Sachs International (US) & 2,699 & 2 & 1.2 & 2 & 0 & 0 & 2.5 & 0.110 & 2.05 \\
\hline Merrill Lynch (US) & 2,515 & 9 & 5.3 & 9 & 0 & 0 & 2.2 & 0.103 & 3.15 \\
\hline Lehman Brothers (US) & 833 & 2 & 1.2 & 2 & 0 & 0 & 2.0 & 0.034 & 2.63 \\
\hline Deutsche Bank (DE) & 737 & 5 & 2.9 & 5 & 0 & 0 & 2.2 & 0.030 & 4.45 \\
\hline Citigroup (US) & 537 & 4 & 2.3 & 3 & 0 & 1 & 2.5 & 0.022 & 4.11 \\
\hline Credit Suisse First Boston $(\mathrm{CH})$ & 357 & 4 & 2.3 & 2 & 0 & 2 & 2.0 & 0.015 & 4.25 \\
\hline Abn Amro (NL) & 317 & 1 & 0.6 & 1 & 0 & 0 & 4.0 & 0.013 & 3.70 \\
\hline Dresdner Kleinwort Wasserstein (UK) & 183 & 1 & 0.6 & 1 & 0 & 0 & 3.0 & 0.007 & 2.90 \\
\hline Commerzbank (DE) & 126 & 1 & 0.6 & 1 & 0 & 0 & 3.0 & 0.005 & 4.50 \\
\hline ING Barings (NL) & 80 & 2 & 1.2 & 0 & 0 & 2 & 3.0 & 0.003 & 4.75 \\
\hline Societe Generale (FR) & 56 & 1 & 0.6 & 1 & 0 & 0 & 2.0 & 0.002 & 5.50 \\
\hline Total/average foreign banks & 11,412 & 40 & 23 & 32 & 0 & 8 & 2.6 & 0.039 & 3.77 \\
\hline Total/average (whole sample) & 51,858 & 171 & 100 & 101 & 29 & 41 & 2.3 & 0.068 & 3.96 \\
\hline
\end{tabular}




\section{Table 5. Determinants of gross spread}

Sample of 171 Italian IPOs from 1999 to 2008. The dependent variable is gross spread, the underwriter's remuneration in percentage of IPO proceeds. Control dummies (coefficients not reported for brevity): industries, years, privatizations, ECOs, private placings, markets, VC-backing. Independent variables: tech bubble is a dummy equal to 1 in case the IPO took place in 1999-2000; firm age is $\log$ of 1 plus firm age in years at the IPO; issue size is the log of IPO proceeds expressed in 2008 Euros; relative issue size is the offer volume in percentage of pre-IPO outstanding shares; dilution ratio is the fraction of newly issued shares as percentage of pre-IPO outstanding shares; institutional allocation is the fraction of shares reserved to institutional investors by prospectus; pre-IPO market return is the return of the FTSE Italia MIB Index over 100 days prior the IPO; market momentum is the number of IPOs in Italy in the 12 months before listing; price revision is the percentage difference between offer price and midpoint of the preliminary price range; claw-back to retail is the fraction of shares shifted from institutional to retail investors, as percentage of the offer volume; greenshoe exercised is a dummy equal to 1 in case the greenshoe option is exercised; foreign underwriter is equal to 1 in case of nonItalian underwriter; underwriter reputation is the fraction of capital raised by each underwriter in our sample of IPOs (scaled at 1 for the 'national champion' Mediobanca); syndicate size is the no. of members in the underwriting syndicate; stabilization not required is a dummy equal to 1 in case price stabilization is not required ex ante by the issuer; liquidity support not required is a dummy equal to 1 in case liquidity support is not required ex ante by the issuer; stabilization (liquidity support) missing is a dummy equal to 1 in case stabilization (liquidity support) was required but not performed. Coefficients and t-statistics (in brackets) are reported. Tstatistics are computed using heteroskedasticity-consistent standard errors (White 1980).

\begin{tabular}{|c|c|c|c|}
\hline & (1) & (2) & (3) \\
\hline \multirow[t]{2}{*}{ Constant } & -8.64 & -8.83 & -11.87 \\
\hline & $(-0.77)$ & $(-0.79)$ & $(-0.99)$ \\
\hline \multirow[t]{2}{*}{ Tech bubble } & $0.10 * * *$ & $0.12 * * *$ & $0.11 * * *$ \\
\hline & $(2.80)$ & $(2.82)$ & $(2.83)$ \\
\hline \multirow[t]{2}{*}{ Firm age } & -0.00 & -0.00 & -0.00 \\
\hline & $(-0.26)$ & $(-0.27)$ & $(-0.28)$ \\
\hline \multirow[t]{2}{*}{ Issue size } & $-0.14 * * *$ & $-0.16 * * *$ & $-0.17 * * *$ \\
\hline & $(-4.63)$ & $(-4.72)$ & $(-4.70)$ \\
\hline \multirow[t]{2}{*}{ Relative issue size } & $0.22 * * *$ & $0.20 * * *$ & $0.19^{* * *}$ \\
\hline & $(2.78)$ & $(3.38)$ & $(4.12)$ \\
\hline \multirow[t]{2}{*}{ Dilution ratio } & $-0.02 * *$ & $-0.02 * *$ & $-0.02 * *$ \\
\hline & $(-2.29)$ & $(-2.28)$ & $(-2.23)$ \\
\hline \multirow[t]{2}{*}{ Institutional allocation } & $-0.23 * *$ & $-0.23 * *$ & $-0.24 * *$ \\
\hline & $(-2.04)$ & $(-2.24)$ & $(-2.17)$ \\
\hline \multirow[t]{2}{*}{ Pre-IPO market return } & -0.21 & -0.19 & -0.15 \\
\hline & $(-0.97)$ & $(-0.93)$ & $(-0.75)$ \\
\hline \multirow{2}{*}{ Market momentum } & -0.65 & -0.61 & -0.55 \\
\hline & $(-1.22)$ & $(-1.12)$ & $(-0.93)$ \\
\hline \multirow[t]{2}{*}{ Price revision } & 4.38 & 4.40 & 5.20 \\
\hline & (1.46) & (1.43) & (1.60) \\
\hline \multirow[t]{2}{*}{ Claw-back to retail } & -0.02 & -0.04 & -0.04 \\
\hline & $(-0.91)$ & $(-1.33)$ & $(-1.57)$ \\
\hline \multirow[t]{2}{*}{ Greenshoe exercised } & -0.02 & -0.03 & -0.03 \\
\hline & $(-0.83)$ & $(-1.29)$ & $(-1.25)$ \\
\hline \multirow[t]{2}{*}{ Foreign underwriter } & & 0.02 & 0.02 \\
\hline & & $(0.70)$ & $(0.65)$ \\
\hline \multirow{2}{*}{ Underwriter reputation } & & $0.10 * * *$ & $0.11^{* * *}$ \\
\hline & & $(2.80)$ & $(2.87)$ \\
\hline \multirow[t]{2}{*}{ Syndicate size } & & 0.01 & 0.00 \\
\hline & & $(0.52)$ & $(0.14)$ \\
\hline \multirow[t]{2}{*}{ Stabilization not required } & & & $-0.10 * *$ \\
\hline & & & $(-2.27)$ \\
\hline \multirow[t]{2}{*}{ Liquidity support not required } & & & 0.01 \\
\hline & & & $(0.41)$ \\
\hline \multirow[t]{2}{*}{ Stabilization missing } & & & -0.03 \\
\hline & & & $(-1.03)$ \\
\hline \multirow[t]{2}{*}{ Liquidity support missing } & & & -0.06 \\
\hline & & & $(-0.78)$ \\
\hline Observations & 171 & 171 & 171 \\
\hline Adjusted R-squared & 0.55 & 0.56 & 0.57 \\
\hline
\end{tabular}




\section{Table 6. Heckman selection model on stabilization activity}

Sample of 167 Italian IPOs from 1999 to 2008 in which the underwriter declared to stabilize stock price if needed. Coefficients and statistics (in brackets) are reported. The dependent variables are: in step 1, stabilization dummy, equal to 1 if the underwriter stabilizes stock price; in step 2, stabilization intensity, i.e. the number of traded shares to stabilize stock price during the first month, scaled by first month turnover. Control dummies (coefficients not reported for brevity): industries, years, privatizations, ECOs, private placings, markets, VC-backing. Independent variables: firm age, issue size, relative issue size, dilution ratio, institutional allocation, price revision, foreign underwriter, underwriter reputation, syndicate size and gross spread are defined in Table 5. 1month BHAR is the instrumented variable for aftermarket performance, obtained using pre-IPO market return, market momentum, underpricing and claw back to retail as instruments. Overallotment is a dummy equal to 1 in case of the underwriter sells shares in excess of the offered volume; greenshoe is a dummy equal to 1 in case the greenshoe option is exercised; naked short is a dummy equal to 1 in case the underwriter overallocates more than $15 \%$ of the offering; overallotment volume are overallocated shares in percentage of offer volume; greenshoe volume is the fraction of greenshoe exercised ( $0-15 \%$ of offer volume); naked short volume is the amount of naked short in percentage of offer volume.

Step 1. Stabilization decision $\quad$ Step 2. Stabilization intensity

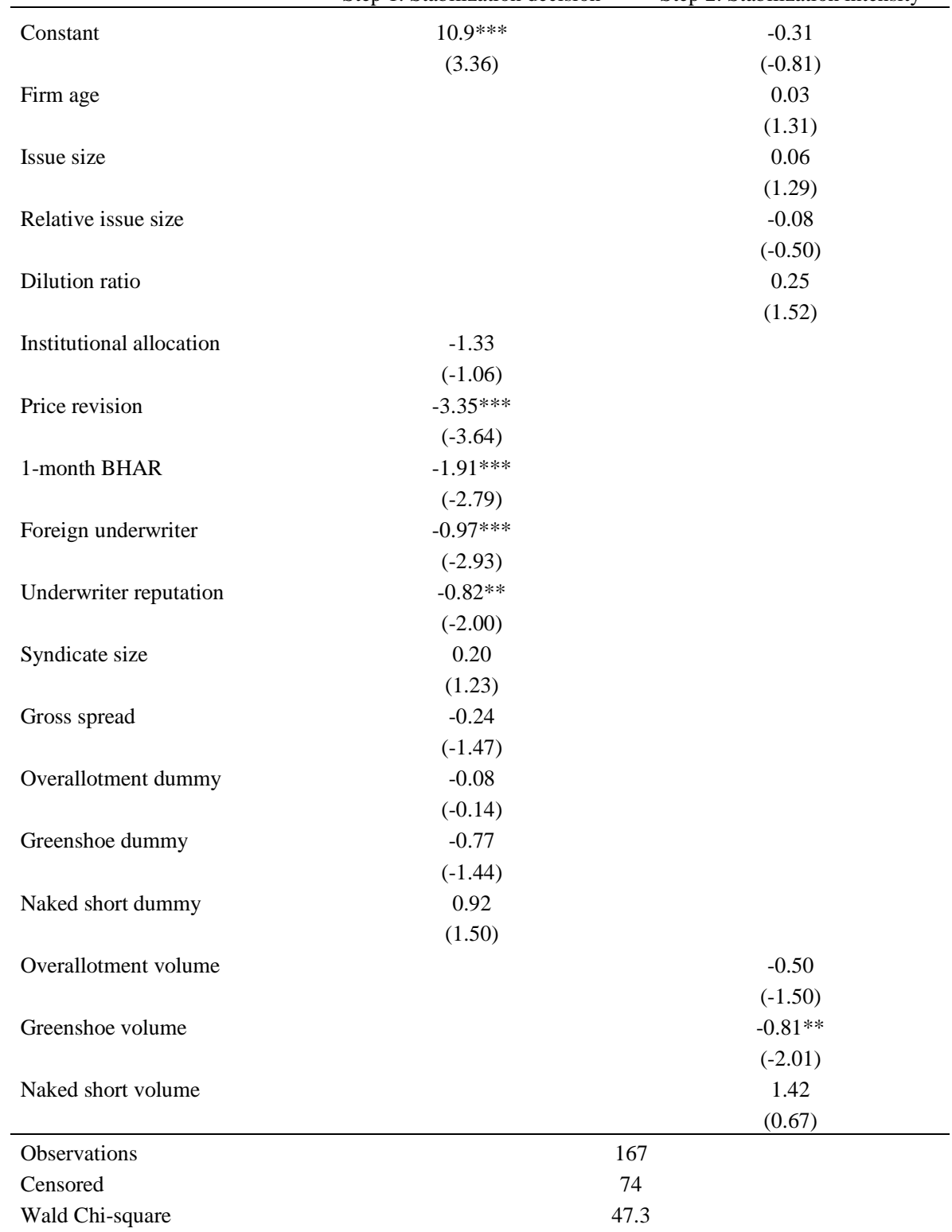




\section{Table 7. Tobit regression on liquidity support}

Sample of 46 Italian IPOs from 1999 to 2008 in which the underwriter declared to provide liquidity support, and for which we have available data on aftermarket provision. Coefficients and t-statistics (in brackets) are reported. Dependent variable is liquidity support intensity, calculated as the number of traded shares to support liquidity as percentage of first month turnover, censored at zero in nonsupported IPOs. Independent variables: firm age, issue size, relative issue size, dilution ratio, institutional allocation, pre-IPO market return, market momentum, price revision, claw back to retail investors, underpricing, foreign underwriter, underwriter reputation, syndicate size and gross spread are defined in Table 5. Greenshoe volume is defined in Table 6. Stabilization performed is a dummy equal to 1 if the underwriter stabilizes aftermarket stock price.

\begin{tabular}{|c|c|c|c|}
\hline & (1) & (2) & (3) \\
\hline \multirow[t]{2}{*}{ Constant } & $0.17 * * *$ & -0.00 & -0.02 \\
\hline & $(2.80)$ & $(-0.02)$ & $(-0.21)$ \\
\hline \multirow[t]{2}{*}{ Firm age } & -0.00 & -0.00 & -0.00 \\
\hline & $(-0.84)$ & $(-0.95)$ & $(-0.15)$ \\
\hline \multirow[t]{2}{*}{ Issue size } & $-0.02 * * *$ & -0.01 & -0.01 \\
\hline & $(-3.21)$ & $(-0.68)$ & $(-0.96)$ \\
\hline \multirow[t]{2}{*}{ Relative issue size } & -0.00 & $-0.01^{* *}$ & $-0.01 * * *$ \\
\hline & $(-1.42)$ & $(-2.32)$ & $(-3.36)$ \\
\hline \multirow[t]{2}{*}{ Dilution ratio } & 0.01 & 0.01 & $0.01 * *$ \\
\hline & $(0.91)$ & $(1.33)$ & $(2.31)$ \\
\hline \multirow[t]{2}{*}{ Institutional allocation } & $-0.05^{*}$ & -0.01 & 0.02 \\
\hline & $(-1.99)$ & $(-0.41)$ & $(0.74)$ \\
\hline \multirow{2}{*}{ Pre-IPO market return } & -0.06 & -0.02 & -0.00 \\
\hline & $(-1.36)$ & $(-0.47)$ & $(-0.08)$ \\
\hline \multirow{2}{*}{ Market momentum } & 0.01 & $0.01 * *$ & $0.01 * * *$ \\
\hline & $(1.25)$ & $(2.05)$ & $(2.83)$ \\
\hline \multirow[t]{2}{*}{ Price revision } & 0.00 & -0.03 & -0.03 \\
\hline & $(0.10)$ & $(-0.99)$ & $(-1.15)$ \\
\hline \multirow[t]{2}{*}{ Claw back to retail } & -0.01 & -0.00 & -0.01 \\
\hline & $(-0.97)$ & $(-0.65)$ & $(-1.31)$ \\
\hline \multirow[t]{2}{*}{ Underpricing } & -0.01 & -0.00 & 0.00 \\
\hline & $(-1.19)$ & $(-0.23)$ & $(0.13)$ \\
\hline \multirow[t]{2}{*}{ Greenshoe volume } & 0.10 & 0.00 & 0.03 \\
\hline & $(1.13)$ & $(0.03)$ & $(0.32)$ \\
\hline \multirow[t]{2}{*}{ Foreign underwriter } & & -0.02 & -0.01 \\
\hline & & $(-1.51)$ & $(-1.43)$ \\
\hline \multirow[t]{2}{*}{ Underwriter reputation } & & -0.00 & -0.00 \\
\hline & & $(-0.98)$ & $(-0.80)$ \\
\hline \multirow[t]{2}{*}{ Syndicate size } & & 0.01 & $0.01 * *$ \\
\hline & & $(1.48)$ & $(2.47)$ \\
\hline \multirow[t]{2}{*}{ Gross spread } & & 0.01 & 0.00 \\
\hline & & $(0.86)$ & $(0.36)$ \\
\hline \multirow[t]{2}{*}{ Stabilization performed } & & & $0.02 * * *$ \\
\hline & & & $(2.84)$ \\
\hline Observations & 46 & 46 & 46 \\
\hline Left-censored observations & 10 & 10 & 10 \\
\hline Prob $>F$ & 0.0001 & 0.0003 & 0.0000 \\
\hline
\end{tabular}


Figure 1. Gross spread distribution by country

Distribution of IPO gross spreads from 1999 to 2008. US data are from Jay Ritter's website (bear.warrington.ufl.edu/ritter/) and Abrahamson et al. (2011), European data are from the EurIPO database (www.euripo.eu). IPOs with proceeds below $\$ 20$ million and $€ 15$ million are excluded because of the effects of economies of scale. The number of observations (IPOs) is reported below the country labels. The black central mark is the median, the edges of the boxes are the 25 th and 75 th percentiles, and the dots represent maximum and minimum values.

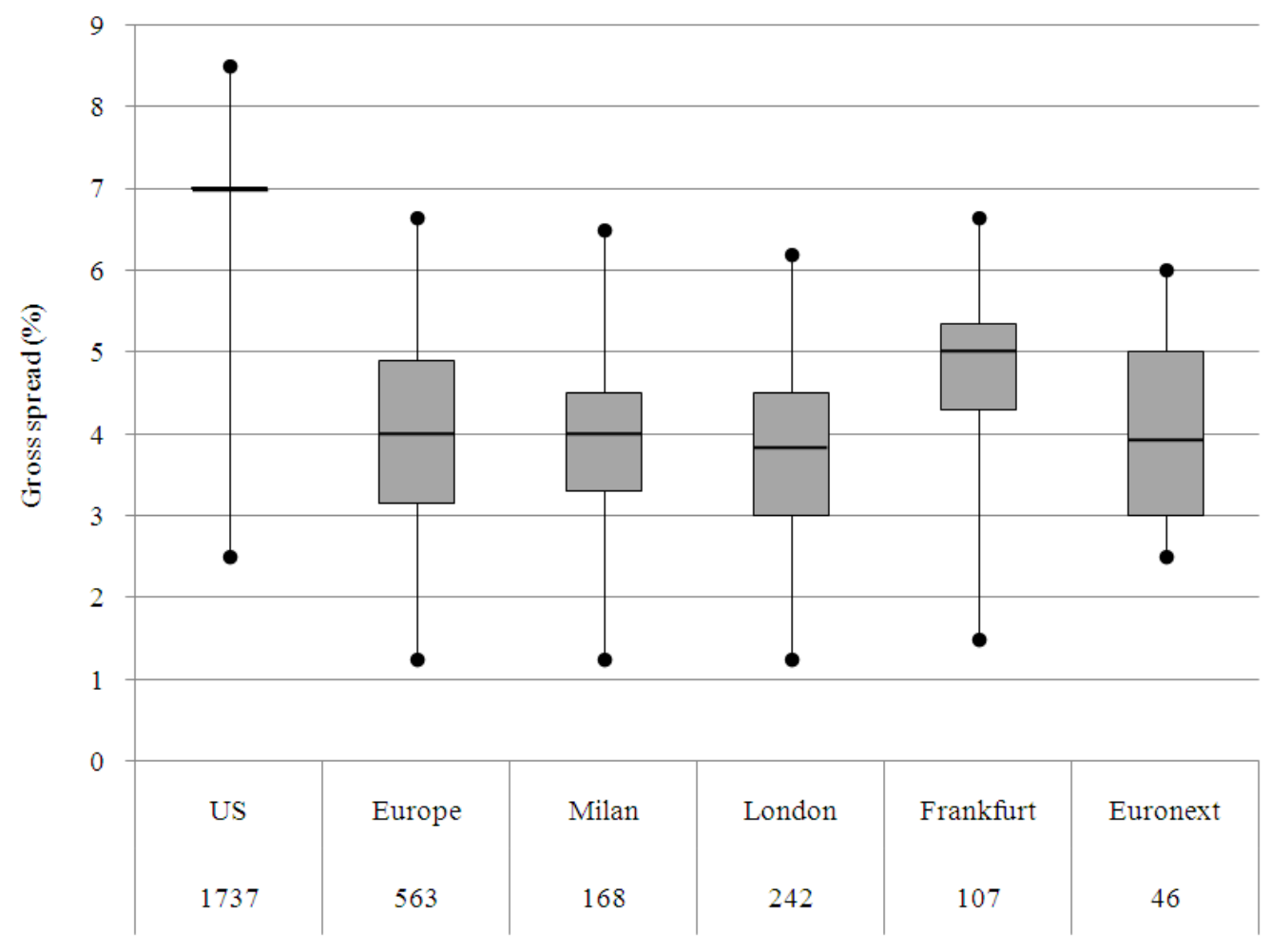




\section{Figure 2. Short covering activity by underwriters}

The graph shows how underwriters have covered their initial short position at the end of the first month of trading. Dark grey is the average fraction covered by greenshoe option, light grey is the average fraction covered by price stabilization. Y-axis reports the short position undertaken by underwriters at the IPO, where $100 \%$ is the sum of overallotment and naked short, if any. Categories on the $\mathrm{x}$-axis refer to the number of days (during the first 30 days of trading) in which the official daily price of the stock was below the offer price.

\section{Short covering activity by underwriters}

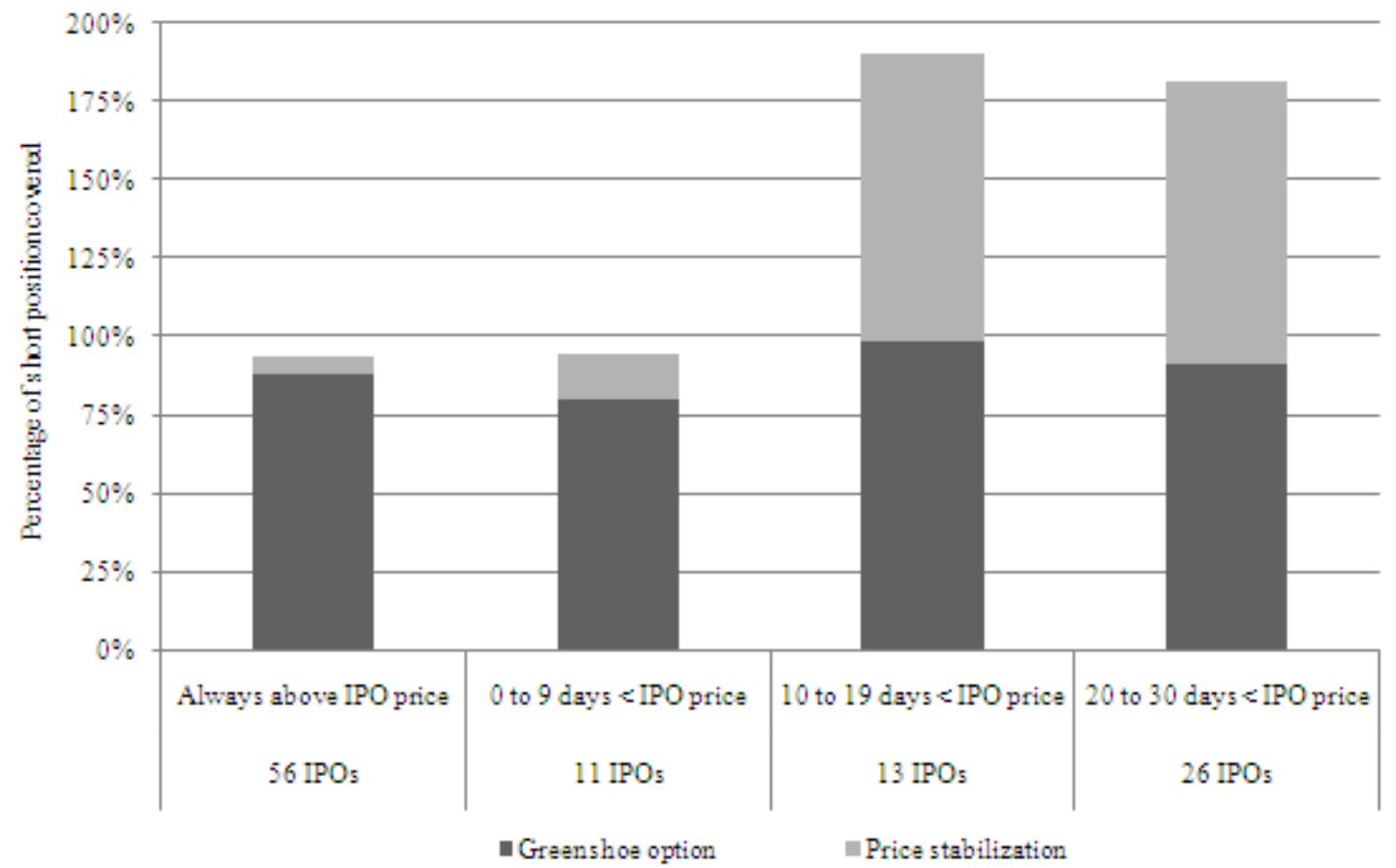




\section{Appendix 1. Variance inflation factors for the regressors in Table 5}

The table reports the variance inflation factor coefficients for each of the independent variables included in the regression on gross spread (Table 5).

\begin{tabular}{lcc} 
Variable & VIF & $1 / \mathrm{VIF}$ \\
\hline Liquidity support not declared & 3.60 & 0.28 \\
Tech bubble & 3.52 & 0.28 \\
Institutional allocation & 2.73 & 0.37 \\
Issue size & 2.65 & 0.38 \\
Greenshoe exercised & 1.96 & 0.51 \\
Market momentum & 1.94 & 0.52 \\
Pre-IPO market return & 1.88 & 0.53 \\
Stabilization not declared & 1.86 & 0.54 \\
Foreign underwriter & 1.84 & 0.54 \\
Price revision & 1.78 & 0.56 \\
Underwriter reputation & 1.75 & 0.57 \\
Stabilization missing & 1.73 & 0.58 \\
Firm age & 1.67 & 0.60 \\
Relative issue size & 1.64 & 0.61 \\
Liquidity support missing & 1.51 & 0.66 \\
Syndicate size & 1.49 & 0.67 \\
Dilution ratio & 1.32 & 0.76 \\
Claw-back to retail & 1.27 & 0.79 \\
\hline Mean VIF & 2.01 & 0.54
\end{tabular}

